\title{
New Distributional Records of Phidippus (Araneae: Salticidae) for Baja California and Mexico: An Integrative Approach
}

\author{
Luis C. Hernández Salgado 1밀 Dariana R. Guerrero Fuentes ${ }^{2}$, Luz A. Garduño Villaseñor ${ }^{1}$, \\ Lita Castañeda Betancur ${ }^{1}$, Eulogio López Reyes ${ }^{1}$ and Fadia Sara Ceccarelli ${ }^{3, *(D)}$ \\ 1 Departamento de Biología de la Conservación, Centro de Investigación Científica y Educación Superior \\ de Ensenada, Ensenada 22860, BC, Mexico; luiscarlos@cicese.edu.mx (L.C.H.S.); \\ luzgv@cicese.edu.mx (L.A.G.V.); lita3023@hotmail.com (L.C.B.); elopez@cicese.mx (E.L.R.) \\ 2 Colección Nacional de Arácnidos, Instituto de Biología, Universidad Nacional Autonóma México, \\ Mexico City 04510, DF, Mexico; darguerrero03@gmail.com \\ 3 CONACYT-Departamento de Biología de la Conservación, Centro de Investigación Científica y Educación \\ Superior de Ensenada, Ensenada 22860, BC, Mexico \\ * Correspondence: ceccarelli@cicese.mx
}

Citation: Hernández Salgado, L.C.; Guerrero Fuentes, D.R.; Garduño Villaseñor, L.A.; Castañeda Betancur, L.; López Reyes, E.; Ceccarelli, F.S. New Distributional Records of Phidippus (Araneae: Salticidae) for Baja California and Mexico: An Integrative Approach. Diversity 2022, 14, 159. https://doi.org/10.3390/ d14030159

Academic Editor: Matjaž Kuntner

Received: 28 September 2021 Accepted: 16 November 2021 Published: 24 February 2022

Publisher's Note: MDPI stays neutral with regard to jurisdictional claims in published maps and institutional affiliations.

Copyright: (c) 2022 by the authors. Licensee MDPI, Basel, Switzerland. This article is an open access article distributed under the terms and conditions of the Creative Commons Attribution (CC BY) license (https:// creativecommons.org/licenses/by/ $4.0 /)$.

\begin{abstract}
Because of its heterogeneity in ecoregions and its varied topography, the Mexican peninsula of Baja California (BCP) is an area of high diversity for many taxa, including spiders. However, a paucity of studies means that the diversity of BCP's spiders is generally poorly known. The North American jumping spider genus Phidippus comprises over 60 species, of which approximately $45 \%$ are found in Mexico. Among those, 6 have been recorded to date from the BCP but adding up the species recorded in nearby states, up to 20 more can be expected. As part of a larger study on the evolution and biogeography of the North American genus Phidippus, the aim here was to explore the diversity of the genus in the BCP using an integrative taxonomic approach and to present new distributional records. Until now, at least ten species have been collected from the $\mathrm{BCP}$, one of which is a new record for Mexico, three new records for the $\mathrm{BCP}$, and at least one undescribed species.
\end{abstract}

Keywords: distribution; diversity; Salticidae

\section{Introduction}

Biogeographical and biodiversity studies rely primarily on knowing the complete distribution of focal taxa as well as the total number of species present in an area. To date, numerous taxonomic groups and vast areas are poorly known owing to a paucity of studies. One such area is the Mexican Baja California Peninsula (BCP), which is the world's second longest peninsula, situated between the latitudes $23^{\circ} \mathrm{N}$ and $32^{\circ} \mathrm{N}$, which means that its climates range from temperate to subtropical. The peninsula's location and orography allow for a variety of ecoregions to exist within the region, such as Mediterranean coastal scrub, mountain coniferous forest, and deserts [1]. While the BCP's relative isolation confers a high number of endemics, especially in plant species [2], the peninsula lies parallel to the mainland, and therefore dispersals and species interchanges are possible from the east as well as from the north. So, considering the geographic and phytogeographic similarities with southern California and Arizona in the United States, as well as Sonora and Sinaloa in Mexico, shared distributional patterns between taxa are expected [3]. Nevertheless, most studies of the region's fauna have focused on vertebrate taxa, while ecologically important groups, such as spiders, have received proportionally much less attention. For the $\mathrm{BCP}$, and particularly its southernmost region, there are approximately 411 described spider species [4].

The spider family Salticidae has the largest number of genera (646) and species (>6000) within the Araneae, comprising about $13 \%$ of the order's species $[5,6]$. A well-known and charismatic salticid genus, Phidippus has 76 described species and includes some of the 
largest jumping spiders in the world, some reaching up to $20 \mathrm{~mm}$ in length $[7,8]$. This genus is distributed from North to Central America, including the Caribbean.

In 2004, Edwards carried out a complete revision of the genus, including a phylogenetic hypothesis based on morphological data. Based on this revision, Mexico contains 36 species of Phidippus, while the BCP has the following 6 recorded species $[7,9,10]:$ P. boei Edwards, 2004, Phidippus californicus Peckham \& Peckham, 1901, P. carneus Peckham \& Peckham, 1896, P. johnsoni (Peckham \& Peckham, 1883), P. nikites Chamberlin \& Ivie, 1935 and P. phoenix Edwards, 2004. However, considering geographic distances and similarities in habitats between California, Arizona, Sonora, and Sinaloa, of the 26 Phidippus species found in the region, several could be present in the BCP. Despite their size and charismatic color patterns, new species of Phidippus are still being found and described, the latest as recently as 2020 [9]. Thus, there also exists a possibility that in the BCP there may be new Phidippus species that are not formally described.

In addition to traditional morphological taxonomic methods, in the past decade and a half, a commonly used data source for species identification in animals, including spiders, has been the DNA "barcoding" region [11-15]. Despite its advantages, such as its universality and a discernable threshold between inter- and intraspecific nucleotide diversity for most taxonomic groups [16,17], the "barcode" region has also been the source of controversy, owing to limitations in correctly delimiting species arising from mitochondrial mechanisms such as incomplete lineage sorting and introgression [18-20] and dependence on the analytic method [21]. Therefore, integrative approaches are preferred over standalone methods [22]. In this study, a combination of morphological examinations, especially adult male and female genitalia [23] and DNA "barcoding" for species identification, is used to explore the diversity of Phidippus in the peninsula.

\section{Materials and Methods}

\subsection{Fieldwork}

Fieldwork was carried out from 2017 to 2021 in a wide range of habitats from shrubland, palm oasis, and pine forests to highly modified rural and urban sites throughout the Baja California Peninsula. The sampling was carried out manually, and Phidippus specimens collected were preserved in $96 \%$ ethanol at $-20^{\circ} \mathrm{C}$. The specimens were placed in the Museum of Arthropods of Baja California (MABC), located at the Ensenada Center for Scientific Research and Higher Education (CICESE) in Baja California, Mexico.

\subsection{Morphological Examinations}

To identify the collected individuals to species level, the taxonomic work of Edwards [7] was used as a reference to identify adult male and female specimens. Body terminology is standard for spiders; genitalia terminology follows Maddison [24]. The following abbreviations are used in the text: ALE—anterior lateral eyes, AER-anterior eyes row, PLE— posterior lateral eyes, PME—posterior median eyes.

The male and female adult genitalia were dissected and examined under a stereoscope and immersed in $96 \%$ alcohol to determine the species. The epigynes were previously cleared following the protocol proposed by Guerrero-Fuentes and Francke [25] but omitting the steps involving hydrochloric and glacial acetic acid. Digital photos of selected jumping spiders were taken using a LUMIX DFC490 camera mounted on a Nikon Z16 APO-A stereo microscope.

\subsection{DNA "Barcode" Analysis}

For the species collected in the $\mathrm{BCP}$, the prosoma and legs were used for DNA extraction, using the DNeasy Blood \& Tissue Kit by Qiagen. Polymerase Chain Reaction (PCR) was carried out following the protocol proposed by the Canadian Centre for DNA Barcoding (CCDB) [22]. The primers used for COI amplification were LCO-1490: 5' GGTCAACAAATCATAAAGATATTGG-3'; HCO-2198: 5'-TAAACTTCAGGGTGACCAAA AAATCA-3', C1-N-2191 (Nancy): 5'-CCCGGTAAAATTAAAATATAAACTTC-3' and C- 
1-J-1751 (Ron): 5'-GGAGCTCCTGACATAGCATTCCC-3'. PCR products for 121 newly collected specimens from the BCP were sent to Macrogen, Inc., Korea, for sequencing.

The sequences were edited and assembled with Geneious Prime 2021.2.2 and Sequencher v 4.1.4. The 121 newly generated "barcode" sequences, all the same length, were uploaded to the Bold Systems v4 database [26] and a Barcode Gap Analysis (BGA) was carried out using the Kimura 2 Parameter substitution model with MUSCLE alignment and pairwise gap deletion to corroborate species identities, particularly in groups where there were no adult specimens. Additionally, 23 reference sequences from previously identified individuals from other localities (Guerrero-Fuentes, in prep), were used in this study to corroborate morphological identifications. The reference sequences were selected for species known to occur in the BCP or nearby states from the U.S.A. (California and Arizona) and Mexico (Sonora and Sinaloa). A list of the species used for reference can be found in Table 1. In addition to the species listed in Table 1, reference sequences belonging to $P$. bidentatus and P. cruentus were included because these two species are widespread in Mexico, and their complete distribution is likely to be unknown. Since most of the reference sequences were obtained with a different primer set, they are missing the first ca. 240 nucleotides of the DNA "barcoding" region. So, rather than using BOLD tools, where missing data are detrimental to calculating genetic distances, a Bayesian phylogenetic tree was reconstructed, since Bayesian phylogenetic relationships can be accurately inferred despite missing data in the matrix [27]. The newly obtained sequences, the reference sequences, plus a sequence belonging to the jumping spider species Habronattus borealis as an outgroup taxon were aligned using the MAFFT v 7 server [28]. Nucleotide substitution models and codon partitioning schemes were selected using Partition Finder v. 1.1.1 [29] under an AICc model selection, which resulted in the following suggested models and partitions: $\operatorname{TrN}+\mathrm{G}$ for COI codon position 1, HKY + I for codon position 2, and TVM $+\mathrm{G}$ for codon position 3. Bayesian phylogenetic inference was then applied in MrBayes v. 3.2.6 [30], running 4 parallel Markov chains for 50 million generations, with a tree sampled every 5000th generation. A consensus tree was then built after discarding the first $25 \%$ as burn-in, and the tree was evaluated by looking for supported nodes (with posterior probabilities greater than 0.95$)$, particularly with regards to species-level clades which included reference sequences.

In cases where there were inconsistencies between the Bayesian tree clades, BGA, and morphological identifications, decisions were made based on the reliability of morphological characters and the DNA "barcoding" sequence fragment. The newly obtained sequences were deposited in the NCBI's GenBank database (accession numbers can be found in the Supplementary Materials Table S1).

Table 1. List of Phidippus species currently recorded for the U.S. states of Arizona and California and the Mexican states of Sonora and Sinaloa, with a note for the species for which a reference sequence of COI was used.

\begin{tabular}{cc}
\hline Extended List of Species * & Species Included as Reference Sequence? \\
\hline Phidippus adumbratus Gertsch, 1934 & YES \\
Phidippus apacheanus Chamberlin \& Gertsch, 1929 & YES \\
Phidippus ardens Peckham \& Peckham, 1901 & NO \\
Phidippus asotus Chamberlin \& Ivie, 1933 & YES \\
Phidippus audax (Hentz, 1845) & YES \\
Phidippus aureus Edwards, 2004 & YES \\
Phidippus boei Edwards, 2004 & YES \\
Phidippus californicus Peckham \& Peckham, 1901 & YES \\
Phidippus carneus Peckham \& Peckham, 1896 & YES \\
Phidippus clarus Keyserling, 1885 & YES \\
Phidippus comatus Peckham \& Peckham, 1901 & YES \\
Phidippus concinnus Gertsch, 1934 & YES \\
Phidippus felinus Edwards, 2004 & NO \\
Phidippus johnsoni (Peckham \& Peckham, 1883) & YES \\
\hline
\end{tabular}


Table 1. Cont.

\begin{tabular}{cc}
\hline Extended List of Species * & Species Included as Reference Sequence? \\
\hline Phidippus kastoni Edwards, 2004 & YES \\
Phidippus nikites Chamberlin \& Ivie, 1935 & YES \\
Phidippus octopunctatus (Peckham \& Peckham, 1883) & YES \\
Phidippus olympus Edwards, 2004 & NO \\
Phidippus phoenix Edwards, 2004 & YES \\
Phidippus pius Scheffer, 1906 & YES \\
Phidippus tigris Edwards, 2004 & NO \\
Phidippus toro Edwards, 1978 & NO \\
Phidippus tux Pinter, 1970 & NO \\
Phidippus tyrannus Edwards, 2004 & NO \\
Phidippus tyrelli Peckham \& Peckham, 1901 & NO \\
Phidippus pacosauritus Edwards, 2020 & NO
\end{tabular}

* Species currently recorded from the BCP are shown in bold.

\section{Results}

Specimens belonging to the genus Phidippus were found in 16 different localities of the Baja California Peninsula (BCP; Supplementary Information Table S1). For this study, a total of 121 newly collected individuals belonging to the genus Phidippus were used for DNA "barcoding", of which 75 were adults and were thus examined morphologically and assigned to 9 described and 1 undescribed species.

\subsection{Taxonomy}

Phidippus adumbratus Gertsch, 1934. New record for Mexico

Supplementary Materials Figure S1

Examined material. MEXICO, Baja California: 3 females (Ph083, Ph088, Ph0147), Sierra Blanca $\left(32.0749^{\circ} \mathrm{N},-116.4528^{\circ} \mathrm{W}, 600 \mathrm{~m}\right)$, Municipio de Ensenada, 27.I.2020, B. Meza leg.; 1 male (Ph076), Mesa Escondido (29.8027 N, $\left.-114.7355^{\circ} \mathrm{W}, 872 \mathrm{~m}\right)$, San Antonio de Las Minas, Municipio de Ensenada, 29.IX.2020, D. Ward Jr leg.

Distribution. California, USA. Baja California, Mexico.

Diagnosis.

Male. Carapace dorsal view, ocular quadrangle covered with gray iridescent scales, median and posterior bands with orange to reddish scales; in frontal view, cheek band strongly marked with white scales and extended to PLE, eyes area with white scales too. Chelicerae are iridescent and striped with a vertical fringe of white and brown setae. Leg fringes are strongly dense and alternating black and white. Abdomen dorsally covered with red scales, basal white band present. Palp with white dorsal stripe from femur to cymbium; embolus is a long, very thin, and recurved spike; palea wider than long, ectal and retrolateral margins smooth.

Female. Carapace covered with sparse white scales, in dorsal view with median ocular band with reddish scales; ocular quadrangular with sparse and tan scales, in frontal view, cheek band and eyes area with white scales. Abdomen covered red with spots, basal, and lateral bands white. Epigynum with long length flaps and straight posteriorly, septum rudimentary to absent, without sagittal ridge, middle slightly depressed, copulatory ducts with one pair of supernumerary bends.

Phidippus boei Edwards, 2004

Supplementary Materials Figure S2

Examined material. MEXICO, Baja California: 1 female (Ph013), Santa Catarina (29.5981 $\left.{ }^{\circ} \mathrm{N},-114.2245^{\circ} \mathrm{W}\right)$, Municipio de San Quintín, 05.VI.2019.

Distribution. Southern California, USA; Baja California and Baja California Sur, Mexico. Diagnosis.

Female. Carapace black; in frontal view, cheek band weakly marked with gray scales. Abdomen is dorsally totally black covered with red scales except on median black stripe, without spots. Epigynum with large length flaps and straight posteriorly, septum absent to distinct and without sagittal ridge, middle slightly depressed, copulatory ducts without supernumerary bends. 
Phidippus californicus Peckham \& Peckham, 1901

Supplementary Materials Figure S3

Examined material. MEXICO, Baja California: 2 male, 1 female (Ph073, Ph099, Ph103), Rancho Mil (32.1205 ${ }^{\circ} \mathrm{N},-115.2611^{\circ}$ W), Ejido El Mayor, Municipio de Mexicali, 23.III.2020, E. López and H. P. Murillo leg.; 1 female (Ph106), 23.IV.2020, same locality, E. López leg.

Distribution. Arizona, California, New Mexico, Oregon, Texas, and Utah, USA; Baja California, Baja California Sur, Chihuahua, Sinaloa, and Sonora, Mexico.

Diagnosis.

Male. Carapace black with white broad submarginal band from PME to thoracic slope or absent; in frontal view, cheek band weakly marked with gray scales. Chelicerae are iridescent and glabrous. Leg fringes are dense and alternating black and white. Abdomen is dorsally covered with red scales except the medial black stripe, basal white band present, white spots or absent. Palp with white dorsal stripe from femur to tibia, cymbium with black setae; embolus is a long, thin, and slightly recurved spike; palea as long as wide, ectal and retrolateral margins smooth.

Female. Carapace in dorsal view with median ocular band present or absent; ocular quadrangular with sparse white scales, in frontal view, cheek band broad and white. Abdomen covered red; spots, basal, and lateral bands white. Epigynum with medium length flaps and straight posteriorly, without septum and sagittal ridge, middle slightly depressed, copulatory ducts with one pair of supernumerary bends.

Phidippus comatus Peckham \& Peckham, 1901. New record for Baja California

Supplementary Materials Figure S4

Examined Material. MEXICO, Baja California: 1 male (MABC-B001), Road to Pino Suárez $\left(32.4099^{\circ} \mathrm{N},-116.2761^{\circ} \mathrm{W}\right)$, Japá, Municipio de Tecate, 02.V.2018, E. López leg.

Distribution. Saskatchewan, Canada; Arizona, California, New Mexico, Nevada, Oregon, Texas, Utah, Washington, and Wyoming, USA; Chihuahua, Coahuila, Durango, Guanajuato, and Hidalgo, Mexico.

\section{Diagnosis.}

Male. Carapace, the median ocular tufts replaced by a dense, horizontal setal crests; ocular quadrangle covered with tan scales, median ocular band white, submarginal band broad from ALE to thoracic slope, cheek band white. Chelicera iridescent and vertically striped with white setae. Leg fringes are dense and alternating black and white. Femur I, ventrally with dark metallic blue distal bulge with gray tuft. Abdomen is dorsally covered with tan scales, basal band white, and white spots are present. Palp with white dorsal stripe from femur to the basal edge of the cymbium; embolus is a long, and recurved spike; palea wider than long, ectal and retrolateral margins smooth.

Phidippus johnsoni (Peckham \& Peckham, 1888)

Supplementary Materials Figure S5

Examined material. MEXICO, Baja California: 1 female (Ph023), El Mogor $\left(32.0339^{\circ} \mathrm{N}\right.$, $-116.6038^{\circ}$ W, 376 m), Valle de Guadalupe, Municipio de Ensenada, 07.V.2018, R. Santos, K. Munguía and E. López leg.; 1 female (Ph015), same locality, 11.I.2019, F. S. Ceccarelli, E. López, K. Munguía and H. P. Murillo leg.; 1 male (Ph022), same locality, 23.IV.2019, E. López leg.; 1 female (Ph014), same locality, 17.VII.2019, J. Quintana leg.; 1 male, 1 female (Ph011, Ph058), same locality, 13.XI.2019, K. Munguía, F.S. Ceccarelli and E. López leg.; 1 male, 3 females (Ph025, Ph091, Ph109, Ph115), same locality, 17.XII.2019, E. López and A. López leg.; 2 males (Ph100, Ph116), same locality, 15.I.2020, K. Munguía and E. López leg.; 1 male, 1 female, juvenile (Ph059, Ph093, Ph037), same locality, 23-24.I.2020, V. Aguilera and E. López leg.; 1 male (Ph098), same locality, 29.I.2020, E. López leg.; 1 female (Ph085), same locality, 14.II.2020; 1 female (Ph016), Xanic $\left(32.0952^{\circ} \mathrm{N},-116.5862^{\circ} \mathrm{W}\right)$, Valle de Guadalupe, 01.XI.2019, E. López leg.; 1 male (Ph067), Sexto Ayuntamiento (31.8812 ${ }^{\circ}$ N, -116.6447 ${ }^{\circ} \mathrm{W}$ ), Municipio de Ensenada, 22.02.2020, A. Alfaro leg.; 1 male (Ph064), El Sauzal $\left(31.8679^{\circ} \mathrm{N},-116.6690^{\circ} \mathrm{W} 32 \mathrm{~m}\right)$, Municipio de Ensenada, 20.02.2020, 1 male (Ph028), 27.02.2020, 1 male (Ph062), 01.03.2020, 1 male (Ph153), 10.III.2020, same locality, L. A. Garduño leg.; 1 male (Ph066), UABC ( $\left.31.8635^{\circ} \mathrm{N},-116.6664^{\circ} \mathrm{W}\right)$, Ciudad de Ensenada, 
Municipio de Ensenada, 11.III.2020, C. Baiza leg.; 2 females (Ph057, Ph092), Colonia Popular 89, $\left(31.8958^{\circ} \mathrm{N},-116.5622^{\circ} \mathrm{W}\right)$, Ciudad de Ensenada, Municipio de Ensenada, 10.IV.2019, H. P. Murillo leg.; 2 males (Ph035, Ph043), Fraccionamiento Carlos Pacheco I, Ciudad de Ensenada (31.8837 $\left.{ }^{\circ} \mathrm{N},-116.6141^{\circ} \mathrm{W}\right)$, Municipio de Ensenada, 06.III.2020,E. López leg.; 1 male (Ph075), Ciudad de Ensenada $\left(31.8637^{\circ} \mathrm{N},-116.6476^{\circ} \mathrm{W}\right)$, Municipio de Ensenada, 16.III.2020, A. Aquino leg.; 1 male (Ph074), Playa San Miguel (31.9014 $\left.{ }^{\circ} \mathrm{N},-116.731^{\circ} \mathrm{W}\right)$, Municipio de Ensenada, 22-III-2020, 1 male (Ph078), same locality, 05.IV.2020, F. S. Ceccarelli leg.; 1 female (Ph068) Ojos Negros $\left(31.8180^{\circ} \mathrm{N},-116.3865^{\circ} \mathrm{W}\right)$, Municipio de Ensenada, 15.II.2020; 1 male (Ph095) Maneadero (31.7189 $\left.\mathrm{N},-116.60^{\circ} \mathrm{W}\right)$, Municipio de Ensenada, 17-III-2019, D. Parra.

Distribution. Abundant throughout southwest Canada, western USA, and northwest Mexico.

\section{Diagnosis}

Male. Carapace is totally black in dorsal and lateral views, cheek band poorly marked with gray and iridescent scales in frontal view. Chelicerae are iridescent and glabrous. Leg fringes are poorly dense with black and white setae. Abdomen are covered with red scales on lateral edges or totally red; in some specimens, spots are barely visible. Palp without dorsal stripe; embolus is a short and thin spike; palea is distinctly longer than wide, ectal margin is squared and retrolateral margin is notched.

Female. Habitus like the male. Abdomen may present white spots; red scales are only on lateral edges. Epigynum with short length flaps and posteriorly divergent, septum and sagittal ridge present, middle slightly depressed, copulatory ducts with supernumerary bends.

Phidippus nikites Chamberlin \& Ivie, 1935

Supplementary Materials Figure S6

Examined material. MEXICO, Baja California: 1 male (Ph021), El Mogor $\left(32.0339^{\circ} \mathrm{N}\right.$, $-116.6038^{\circ}$ W, 376 m), Valle de Guadalupe, Municipio de Ensenada, 16.X.2019, E. López; 1 female (Ph080), 15.06.2020, same locality. Baja California Sur: 1 male (Ph135), Vizcaíno (27.2734 $\mathrm{N},-113.5338)$, Municipio de Mulegé, 20.IX.2020, H. P. Murillo leg.

Distribution. California, Idaho, Nevada, and Oregon, USA; Baja California, Mexico. Diagnosis.

Male. Carapace dorsum is totally covered with red scales; in the frontal view, cheek band is weakly marked with gray scales. Chelicerae are iridescent and glabrous. Leg fringes are poorly dense, alternating black and white, with a few reddish to orange scales. Abdomen dorsally covered with red scales. Palp without dorsal stripe, cymbium with black setae; embolus is a short and recurved blade; palea longer than wide, ectal margin extended distally and retrolateral margin notched.

Female. General color pattern is like the male. Carapace, cheek band broad and red. Abdomen is covered red; spots are not visible. Epigynum with short length flaps and convergent posteriorly, without septum and sagittal ridge, middle depressed, copulatory ducts with one to two pairs of supernumerary bends.

Phidippus octopunctatus (Peckham \& Peckham, 1883). New record for Baja California. Supplementary Materials Figure S7

Examined material. MEXICO, Baja California: 1 female, (Ph150), El Mogor $\left(32.0339^{\circ} \mathrm{N}\right.$, -116.6038 ${ }^{\circ}$ W, 376 m), 20.VIII.2020, E. López leg.; 1 male (Ph087), El Sauzal (31.8679 N, $-116.6690^{\circ}$ W, 32 m), Municipio de Ensenada, 10.IX.2020, L. A. Garduño leg.

Distribution. Widespread from western to central USA; northern to central Mexico.

\section{Diagnosis.}

Male. Carapace dorsum is totally covered with gray scales; in the frontal view, cheek band is weakly marked with gray scales. Chelicerae are black, dull, and glabrous. Leg fringes are poorly dense, alternating black and white. Abdomen dorsally covered with gray scales. Palp with white or gray dorsal stripe, cymbium almost black, with some white setae; embolus is a long and slightly recurved spike; palea wider than long, ectal and retrolateral margins smooth 
Female. General color pattern is like the male. Carapace, cheek band broad, with gray and white scales. Abdomen covered with gray scales, without spots or bands. Epigynum without flaps, anterior depressed, copulatory ducts with one pair of supernumerary bends.

Phidippus phoenix Edwards, 2004

Supplementary Materials Figure S8

Examined material. MEXICO, Baja California: 1 male (Ph070), Ampliación La Moderna $\left(31.8693^{\circ} \mathrm{N},-116.6431^{\circ} \mathrm{W}\right)$, Ciudad de Ensenada, Municipio de Ensenada, 16.III.2020; 1 male (Ph077), 01.III.2020; 1 male, 1 female (Ph071, Ph072), 23.III.2020; 1 male (Ph079), 24.IV.2020, same locality, F. S. Ceccarelli leg.; 1 female (Ph096), Punta Colonet (31.0764 ${ }^{\circ}$, -116.2761 ${ }^{\circ}$ W), Municipio de Ensenada, 05.VIII.2019, B. Meza leg.; 6 males, 8 females (Ph031, Ph032, Ph034,Ph045, Ph046, Ph047, Ph048, Ph050, Ph052, Ph053, Ph054, Ph055, Ph056, Ph060), same locality, 25.I.2020, L. A. Garduño, E. López, and H. P. Murillo leg.; 1 female (Ph102), Santa Catarina $\left(29.598151^{\circ} \mathrm{N},-114.224484^{\circ} \mathrm{W}\right)$, Municipio de San Quintín, 06.V.2019, K. Munguía leg.; 1 female (Ph010), 05.VI.2019, same locality, K. Munguía, E. López, and H. P. Murillo, leg.; 1 male (Ph090), CICESE $\left(31.8657^{\circ} \mathrm{N},-116.6625^{\circ} \mathrm{W}\right)$, El Sauzal, Ciudad de Ensenada, Municipio de Ensenada, 15.II. 2020, L. Sankey leg.; 1 male (Ph081), 01.III.2020, same locality, E. López leg.; 3 males (Ph030, Ph039, Ph069), 10-17.IV.2020, same locality, L. A. Garduño leg.

Distribution. Southern Arizona and southern California, USA; Baja California and Baja California Sur, Mexico.

Diagnosis.

Male. Carapace in dorsal view with white median ocular band; in frontal view, cheek band very broad with white scales. Chelicerae are iridescent and fringed, with white scales and setae. Leg fringes are dense and white. Abdomen dorsally covered with red scales. Palp with white dorsal stripe from femur to cymbium; embolus is a long and recurved spike; palea is wider than long, ectal and retrolateral margins smooth.

Female. Carapace in dorsal view with white median ocular band; in frontal view, cheek and submarginal bands fused, and colored white. Abdomen with lateral edges red or white; spots and lateral bands white. Epigynum with medium length flaps and posteriorly divergent, septum rudimentary and without sagittal ridge, middle slightly depressed, copulatory ducts with one pair of supernumerary bends.

Phidippus tux Pinter, 1970. New record for Baja California.

Supplementary Materials Figure S9

Examined material. MEXICO, Baja California Sur: 1 female (Ph158) Oasis Carambuche $\left(26.1293^{\circ} \mathrm{N},-112.0167^{\circ} \mathrm{W}, 300 \mathrm{~m}\right)$, La Purísima, Municipio de Comondú, IX.2020, H. P. Murillo leg.

Distribution. Arizona, USA; Nayarit, Jalisco and Sonora, Mexico.

Diagnosis.

Female. Carapace dorsum is totally covered with yellow scales; in the frontal view, cheek band is strongly marked with yellow to white scales, the area of eyes covered with brown to tan scales. Abdomen totally covered with yellow scales, or partially covered with a posterior abdominal area dark and U-shaped, spots and bands are white. Epigynum with medium length and wide flaps, divergent posteriorly; with septum and sagittal ridge, middle depressed, copulatory ducts without supernumerary bends.

The expanded distributions of the new records, P. adumbratus, P. comatus, P. octopunctatus and P. tux, can be found in Figure 1.

\subsection{DNA "Barcoding"}

Based on the BGA in the Bold Systems v4 database, the 121 individuals belong to 10 species (see Supplementary Materials Table S2). Individuals tentatively assigned to undescribed species (Phidippus spp. 1 and 3) were found to have a distance below $2 \%$ to their nearest neighbor, which grouped them with $P$. boei. The remaining species ( 9 identified and 1 unidentified) were consistently delimited as separate from each other, based on the BGA. The nucleotide alignment upon which the COI phylogenetic tree was based consisted 
of 145 taxa and 1204 sites, which included the "barcode" region as well as ca. 500 additional nucleotides because the reference sequences were amplified using different primer sets (Guerrero-Fuentes et al., in prep.). The Bayesian consensus tree recovered 12 lineages for the Phidippus species from the BCP (Figure 2). The sequences from the individuals that formed clades with the identified reference species, and which were also identified morphologically, belonged to the following six species: P. adumbratus, P. boei, P. californicus, $P$. nikites, P. octopunctatus and P. phoenix. A further two species, which were identified morphologically as $P$. comatus and $P$. johnsoni, did not form a clade in the tree with their respective reference species. Rather, $P$. comatus from the BCP fell into an unresolved group (albeit with the $P$. comatus reference species) and the $P$. johnsoni were in a clade with the $P$. concinnus reference species, sister to the $P$. johnsoni reference species. Reference sequences were not available for $P$. $t u x$, so its identification was based on female genital morphology and other morphological traits. A further three well supported clades within the tree did not have any associated reference sequences. For two of these clades, morphological identification was not possible owing to a lack of adult specimens. For a third clade (Phidippus sp. 2), preliminary morphological examinations pointed to the species belonging to the insignarius group following Edwards' [7] revision for the genus.

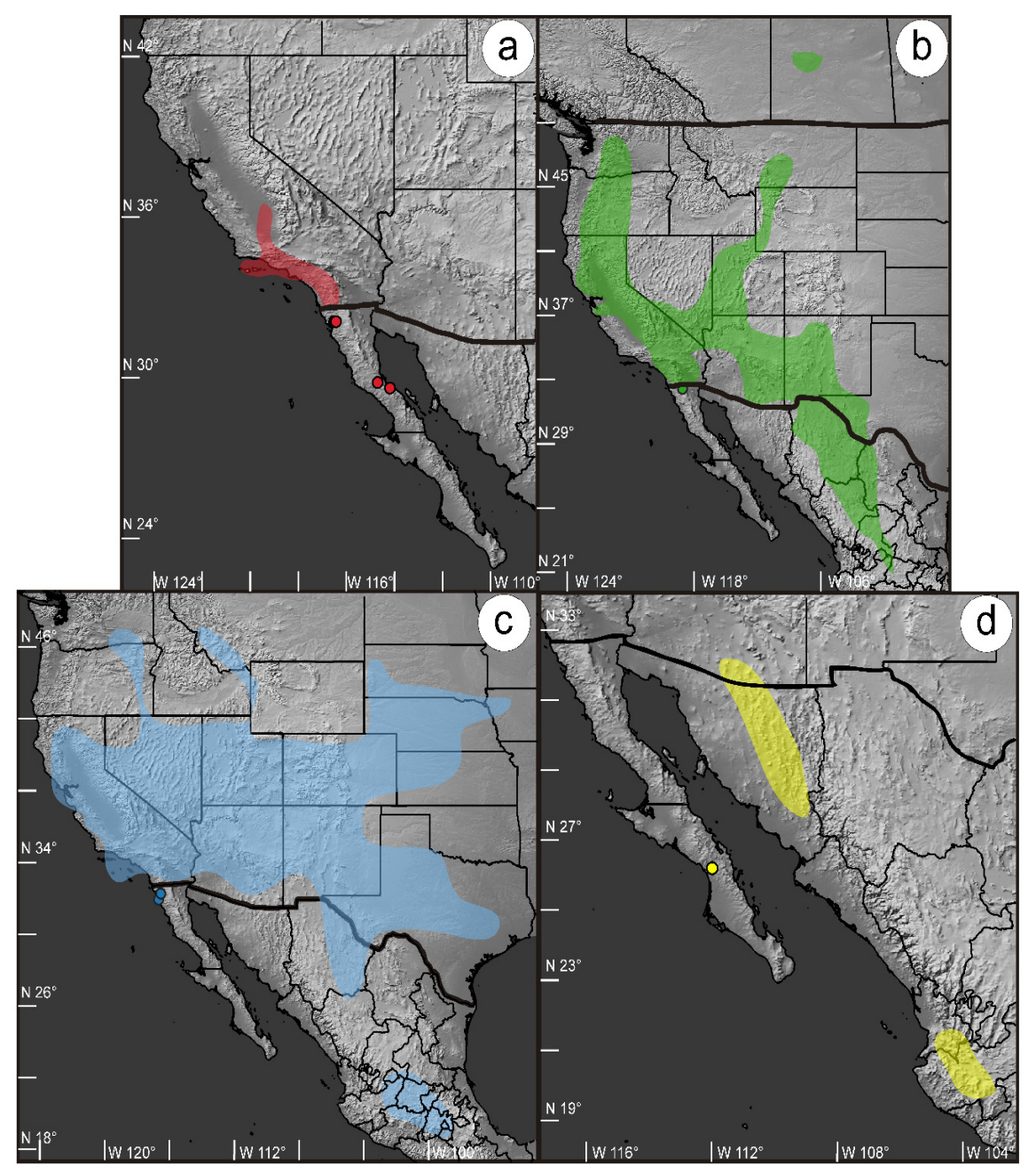

Figure 1. Distributional maps of the four Phidippus species with new distributional records in this study, namely, P. adumbratus (a), P. comatus (b), P. octopunctatus (c) and P. tux (d). Colored polygons represent the previously known distributions, based on Edwards (2004) and colored circles with black outlines represent the localities of the samples from this study. Country borders are shown with thick black lines, and thin black lines represent state borders for Mexico and the U.S.A. and Canadian provinces. 


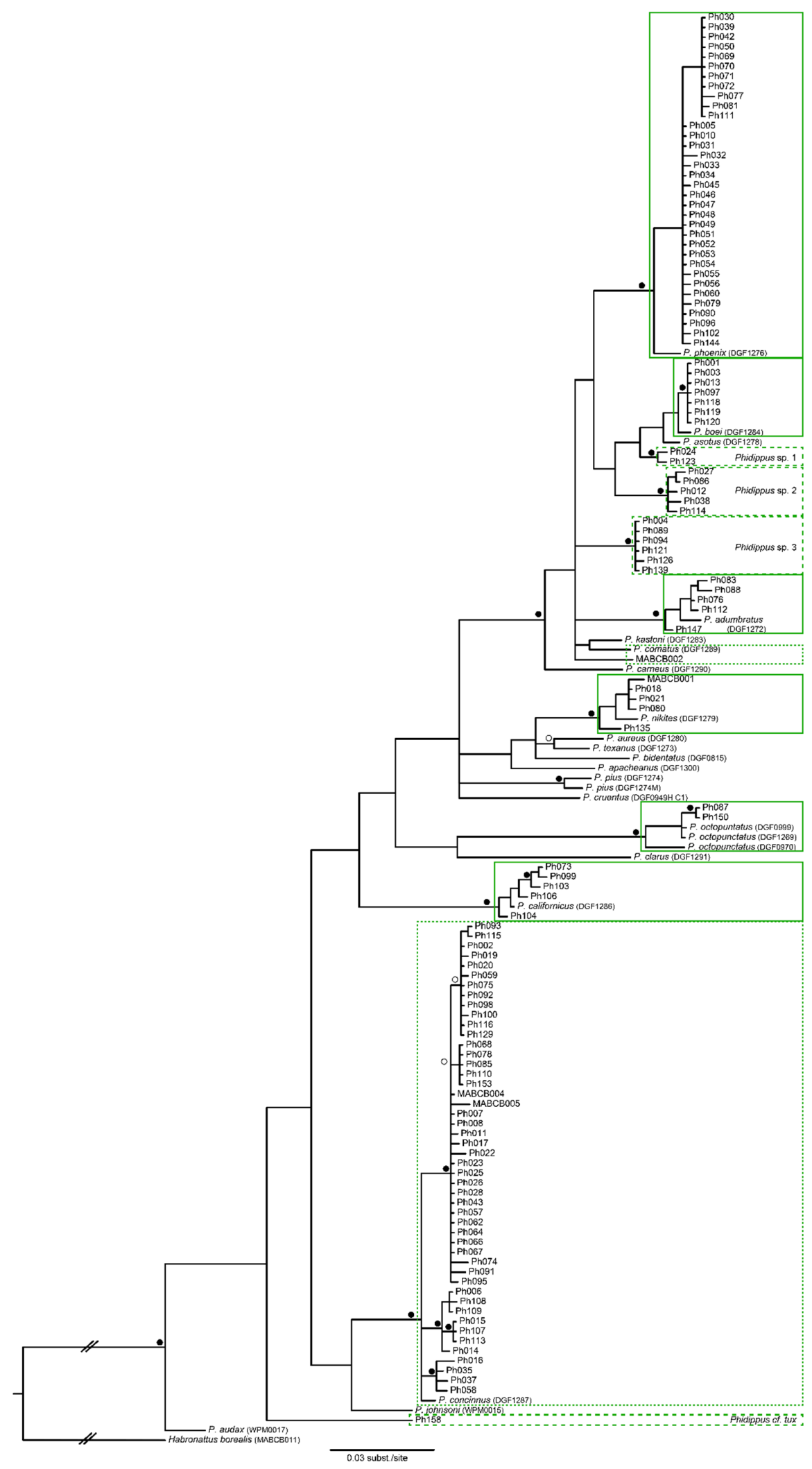

Figure 2. Bayesian phylogenetic tree of COI sequences of Phidippus individuals from this study, marked with DNA codes (cross-reference with Supplementary Materials Table S1) and reference sequences with codes in brackets following the species names. Green boxes with solid lines outline the species identified by morphology, while dotted lines represent species with uncertainties based on DNA sequences and/or unidentified specimens. Solid black circles at nodes represent posterior probability values $>0.95$ and white circles posterior probabilities between 0.9 and 0.95 . 


\section{Discussion}

In this study, no comments will be made with regards to the phylogenetic relationships between the species since many nodes are not supported, as COI is generally not ideal for resolving deeper relationships, added to the fact that the results here show a gene tree and not a species tree. It has been reported that the complex evolutionary dynamics of COI could contribute to misleading node resolution in jumping spiders [31-34]. In any case, in this study the tree was built for species grouping, which worked for most species, including the grouping of juveniles (which cannot be reliably identified using morphological features) with adults. The Barcode Gap Analyses helped to further discriminate between species. DNA barcoding has been shown to be a generally reliable method for discriminating species [12-14,35] and as part of a combined (integrative taxonomic) approach; the molecular and morphological data complemented each other for assigning individuals to Phidippus species.

Inconsistencies between morphological and COI tree-based identifications were found for two species and may be attributed to certain limitations commonly found in COI, such as introgressive hybridization and incomplete lineage sorting [18]. In the case of P. comatus, increased sampling throughout the species' distributional range, as well as more specimens belonging to sister taxa, may help resolve the nodes. The morphological examination of the male specimen from the BCP left no doubt about its identity, and the fact that it was collected near its known distributional range and in a similar environment and altitude to those reported by Edwards [7] ruled out the possibility of an accidental record, even though only a single individual was collected.

The incongruence between the COI of the BCP's P. johnsoni grouping (with P. concinnus) and morphological identification pointed to a slightly more complex situation. Genital examination clearly confirmed the distinct identities of $P$. johnsoni and P. concinnus. $P$. johnsoni is a widespread species, found from western Canada, throughout western USA, to as far south as northwestern Mexico. Close morphological examinations of $P$. johnsoni pointed to sympatric morphotypes with regard to abdomen color patterns, but a lack of population genetic studies on this species made it difficult to reach conclusions about the structuring of these populations and whether P. johnsoni may in fact be a species complex with conserved genital morphology. Thus, $P$. concinnus may have diverged from a most recent common ancestor of a $P$. johnsoni population. This would explain why the BCP $P$. johnsoni sequences cluster with $P$. concinnus instead of with its reference $P$. johnsoni sequence, which came from an individual collected in Grant County, Washington state, USA.

Since no reference sequences were available for $P$. tux , its identity was based solely on morphological examination of one single specimen collected during this study. A single individual might lead to doubts about whether it is an accidental record, perhaps a case of accidental faunal translocation. Further sampling in and around the locality where this P. tux individual was found, as well as from its complete distributional range, will be necessary for an in-depth study of how it got to the BCP. If indeed there is an established population of $P$. tux in the $\mathrm{BCP}$, and since the locality lies in the southern part of the peninsula, it is likely that the population is genetically closer to the $P$. tux populations from Mexico's west coast states and may either be a relictual population as a result of the peninsula's separation from the mainland during the last 10 million years [3,36], or it may be an established population following westward dispersal from the mainland to the peninsula.

The other confirmed species for which new records from Mexico and the $\mathrm{BCP}$ are presented are P. octopunctatus, which has a widespread distribution, and the new records are near the limits of its known distribution, and P. adumbratus, which until now was recorded from the California floristic province, an area of high endemism $[37,38]$ located along the coast of the North American Pacific. In this study, P. adumbratus is newly recorded for Mexico, as well as from a new ecoregion, namely, Baja California's Central Desert ecoregion, as defined by Gonzalez-Abraham et al. [1]. Perhaps this distribution could be explained by Hill and Edwards' [39] hypothesis on the dispersal routes of Phidippus species since 
the Last Glacial Maximum (LGM; 20 Ka), whereby P. adumbratus may have migrated from the southern part of the BCP northwards, reaching California as the climate changed and warmed.

Three clades in this study's COI Bayesian phylogeny did not include any of the reference species, perhaps because they are species for which reference sequences were not available, or perhaps they are, to date, undescribed species. For two of the unidentified morphospecies, adult specimens were not available; however, the BGA placed them with P. boei. A third species probably belongs to the insignarius group following Edwards' [7] classification. However, to accurately determine whether these individuals belong to undescribed species, further sampling and a full taxonomic work will be necessary.

In the Baja California Peninsula, many unexplored places are difficult to access for sampling, and many Phidippus species, despite their relatively large size, are difficult to find in the field owing to habits such as hiding at the base of dense cactus spines, which complicates collecting. Although this study contributed to knowledge of the diversity of spiders in the BCP and the distributional range and richness of Phidippus, which increased from six to nine species, increased sampling efforts are required to uncover the BCP's true richness and diversity of Phidippus spiders. After the present contribution, the number of known spider species for the BCP increased from 396 to 400, and the diversity of Salticidae in the BCP increased from 37 to 41 species, based on the most recent data published on the diversity of the peninsula's spiders $[4,10]$. Furthermore, several Phidippus species are more widely distributed than previously thought. This new information has direct implications for both ecological and historical biogeographic studies. For ecological biogeography, such as Species Distribution Modeling, a higher number of known distributional datapoints allow for models with greater accuracy and precision [40]. As for historical biogeographical implications, the fact that the northern part of the BCP was found to harbor a great diversity of Phidippus suggests that it could be an ancestral area for at least some taxa. Additionally, several taxa may have dispersed to the BCP, as proposed by Hill and Edwards [39]; however, this hypothesis only considers a fraction of the diversity present in the BCP. Given the fact that the species found in the BCP belong to different species groups as defined by Edwards [7], species richness as well as phylogenetic diversity [41] for Phidippus is likely to be high for this area. A more in-depth molecular phylogenetic study of Phidippus and related genera will shed more light on the historical biogeographic and macroevolutionary processes of these spiders.

Supplementary Materials: The following are available online at https:/ / www.mdpi.com/article/10 $.3390 /$ d14030159/s1. Table S1: Individual codes, species identification, collection information and GenBank accession numbers for the COI sequences of the Phidippus species collected in the Baja California Peninsula for this study; Table S2: Barcode Gap Analysis result. Figure S1: Photographs of Phidippus adumbratus Gertsch, 1934; Figure S2: Photographs of Phidippus boei Edwards, 2004; Figure S3: Photographs of Phidippus californicus Peckham \& Peckham, 1901; Figure S4: Photographs of Phidippus comatus Peckham \& Peckham, 1901; Figure S5: Photographs of Phidippus johnsoni (Peckham \& Peckham, 1888); Figure S6: Photographs of Phidippus nikites Chamberlin \& Ivie, 1935; Figure S7: Photographs of Phidippus octopunctatus (Peckham \& Peckham, 1883); Figure S8: Photographs of Phidippus phoenix Edwards, 2004; Figure S9: Photographs of Phidippus tux Pinter, 1970.

Author Contributions: Conceptualization, L.C.H.S., L.A.G.V. and F.S.C.; methodology, L.C.H.S., L.A.G.V., D.R.G.F., E.L.R., F.S.C. and L.C.B.; formal analysis, L.C.H.S. and F.S.C.; investigation, L.C.H.S., L.A.G.V., D.R.G.F., F.S.C.; resources, F.S.C.; data curation, L.C.H.S., L.A.G.V., D.R.G.F., F.S.C.; writing-original draft preparation, L.C.H.S., L.A.G.V., D.R.G.F., F.S.C.; writing-review and editing, L.C.H.S., L.A.G.V., D.R.G.F., F.S.C.; visualization, L.C.H.S. and F.S.C.; supervision, F.S.C.; project administration, F.S.C. and E.L.R.; funding acquisition, F.S.C. All authors have read and agreed to the published version of the manuscript.

Funding: This work was funded by Fondo Sectorial de Investigación para la Educación SEPCONACYT Investigación Científica Básica 2017-2018 grant A1-S-15134 to F.S.C.; Jiji Foundation grant of the International Community Foundation awarded to F.S.C. (award number 20180127) and Becas Nacionales CONACYT to Luis Carlos Hernández. 
Institutional Review Board Statement: Not applicable.

Data Availability Statement: DNA sequences derived from this study are deposited in the NCBI's GenBank database (accession numbers can be found in the Supplementary Materials Table S1).

Acknowledgments: We thank Alberto López Aleman, Ana Alfaro, Andrés Martínez Aquino, Bill and Mary Clark, Bryan Meza, Christian Baiza, D. Parra, Damian Elías, David M Ward Jr, Diego de Pedro, Edna Arvizu, Elvia Plascencia, Guilhermi Azevedo, Heriberto Pérez Murillo, Jorge Quintana, Khutzy Munguía Ortega, Le Roy Sankey, Mario Salazar Ceseña, Marshal Hedin, and Sergio Gonzalez Piñuelas, for helping us collect Phidippus. We also thank G.B. Edwards for his comments on the identification of species, in particular, for confirming the identity of Phidippus tux, and Aurora Cabrera and Ana Salgado for their contribution to the English language revision of this manuscript. We also thank Matjaž Kuntner and three anonymous referees for their constructive comments on earlier versions of the manuscript. We would also like to acknowledge the financial support granted by the Posgrado en Ciencias de la Vida, CICESE, to L.C.H.S. for a research stay.

Conflicts of Interest: The authors declare no conflict of interest.

\section{References}

1. González-Abraham, C.E.; Garcillán, P.P.; Ezcurra, E.; Trabajo de Ecorregiones, G.d.T.d.E. Ecorregiones de La Península de Baja California: Una Síntesis. Bot. Sci. 2010, 87, 69. [CrossRef]

2. Rebman, J.P.; Gibson, J.; Rich, K. Annotated Checklist Of The Vascular Plants Of Baja California, Mexico. Proc. San Diego Soc. Nat. Hist. 2016, 45, 1-24.

3. Riddle, B.R.; Hafner, D.J.; Alexander, L.F.; Jaeger, J.R. Cryptic Vicariance in the Historical Assembly of a Baja California Peninsular Desert Biota. Proc. Natl. Acad. Sci. USA 2000, 97, 14438-14443. [CrossRef] [PubMed]

4. Jiménez, M.L.; Palacios-cardiel, C.; Maya-morales, J.; Edwin Berrian, J.; Ibarra Núñez Jiménez, G. Nuevos Registros De Arañas (Arachnida: Araneae) Para La Región Del Cabo, Península De Baja California, México New Records Of Spiders (Arachnida: Araneae) For Cape Region, Baja California Peninsula, Mexico. Acta Zool. Mex. 2018, 34, 1-13. [CrossRef]

5. Peng, X.J.; Tso, I.M.; Li, S.Q. Five New and Four Newly Recorded Species of Jumping Spiders from Taiwan (Araneae: Salticidae). Zool. Stud. 2002, 41,1-11.

6. World Spider Catalog. Available online: https://wsc.nmbe.ch/ (accessed on 31 August 2020).

7. Edwards, G.B. Revision of the Jumping Spiders of the Genus Phidippus (Araneae: Salticidae). Occas. Pap. Florida State Collect. Arthropods 2004, 11, 1-158.

8. Maddison, W.P. A Phylogenetic Classification of Jumping Spiders (Araneae: Salticidae). J. Arachnol. 2015, 43, 231. [CrossRef]

9. Edwards, G.B. Description of Phidippus Pacosauritus Sp. Nov. (Salticidae: Salticinae: Dendryphantini: Dendryphantina) with a Reanalysis of Related Species in the Mystaceus Group. Peckhamia 2020, 221.1, 1-18.

10. Richman, D.B.; Cutler, B.; Hill, D.E. Salticidae of North America, Including Mexico Salticidae of North America, Including Mexico. Peckhamia 2012, 95.3, 1-88.

11. Barrett, R.D.H.; Hebert, P.D.N. Identifying Spiders through DNA Barcodes. Can. J. Zool. 2005, 83, 481-491. [CrossRef]

12. Hebert, P.D.N.; Stoeckle, M.Y.; Zemlak, T.S.; Francis, C.M. Identification of Birds through DNA Barcodes. PLoS Biol. 2004, 2, 1657-1663. [CrossRef]

13. Blagoev, G.A.; deWaard, J.R.; Ratnasingham, S.; deWaard, S.L.; Lu, L.; Robertson, J.; Telfer, A.C.; Hebert, P.D.N. Untangling Taxonomy: A DNA Barcode Reference Library for Canadian Spiders. Mol. Ecol. Resour. 2016, 16, 325-341. [CrossRef] [PubMed]

14. Naseem, S.; Tahir, H.M. Use of Mitochondrial COI Gene for the Identification of Family Salticidae and Lycosidae of Spiders. Mitochondrial DNA Part A DNA Mapp. Seq. Anal. 2016, 29, 96-101. [CrossRef] [PubMed]

15. Astrin, J.J.; Höfer, H.; Spelda, J.; Holstein, J.; Bayer, S.; Hendrich, L.; Huber, B.A.; Kielhorn, K.H.; Krammer, H.J.; Lemke, M.; et al. Towards a DNA Barcode Reference Database for Spiders and Harvestmen of Germany. PLoS ONE 2016, 11, e0162624. [CrossRef] [PubMed]

16. Čandek, K.; Kuntner, M. DNA Barcoding Gap: Reliable Species Identification over Morphological and Geographical Scales. Mol. Ecol. Resour. 2014, 15, 268-277. [CrossRef] [PubMed]

17. Coddington, J.A.; Agnarsson, I.; Cheng, R.C.; Čandek, K.; Driskell, A.; Frick, H.; Gregorič, M.; Kostanjšek, R.; Kropf, C.; Kweskin, M.; et al. DNA Barcode Data Accurately Assign Higher Spider Taxa. PeerJ 2016, 2016, e2201. [CrossRef] [PubMed]

18. Funk, D.J.; Omland, K.E. Species-Level Paraphyly and Polyphyly: Frequency, Causes, and Consequences, with Insights from Animal Mitochondrial DNA. Annu. Rev. Ecol. Evol. Syst. 2003, 34, 397-423. [CrossRef]

19. Vences, M.; Thomas, M.; Bonett, R.M.; Vieites, D.R. Deciphering Amphibian Diversity through DNA Barcoding: Chances and Challenges. Philos. Trans. R. Soc. B Biol. Sci. 2005, 360, 1859-1868. [CrossRef] [PubMed]

20. Ceccarelli, F.S.; Sharkey, M.J.; Zaldívar-Riverón, A. Species Identification in the Taxonomically Neglected, Highly Diverse, Neotropical Parasitoid Wasp Genus Notiospathius (Braconidae: Doryctinae) Based on an Integrative Molecular and Morphological Approach. Mol. Phylogenet. Evol. 2012, 62, 485-495. [CrossRef] 
21. Meier, R.; Blaimer, B.B.; Buenaventura, E.; Hartop, E.; von Rintelen, T.; Srivathsan, A.; Yeo, D. A Re-Analysis of the Data in Sharkey et Al.'s (2021) Minimalist Revision Reveals That BINs Do Not Deserve Names, but BOLD Systems Needs a Stronger Commitment to Open Science. Cladistics 2021, 1-12. [CrossRef] [PubMed]

22. Schlick-Steiner, B.C.; Steiner, F.M.; Seifert, B.; Stauffer, C.; Christian, E.; Crozier, R.H. Integrative Taxonomy: A Multisource Approach to Exploring Biodiversity. Annu. Rev. Entomol. 2010, 55, 421-438. [CrossRef]

23. Huber, B.A. The significance of copulatory structures in spider systematics. In Biosemiotik-Praktische Anwendung und Konsequenzen Fur Die Einzelwissenschaften; Schult, J., Ed.; VWB Verlag: Berlin, Germany, 2004; pp. 89-100.

24. Maddison, W.P. Pelegrina Franganillo and Other Jumping Spiders Formerly Placed in the Genus Metaphidippus (Araneae: Salticidae). Bull. Museum Comp. Zool. 1996, 154, 215-368.

25. Guerrero-Fuentes, D.R.; Francke, O.F. Taxonomic Revision of Anicius Chamberlin, 1925 (Araneae: Salticidae), with Five New Species of Jumping Spiders from Mexico. Zootaxa 2019, 4638, 485-506. [CrossRef] [PubMed]

26. Ratnasingham, S.; Hebert, P.D.N. BOLD: The Barcode of Life Data System: Barcoding. Mol. Ecol. Notes 2007, 7, 355-364. [CrossRef] [PubMed]

27. Wiens, J.J.; Moen, D.S. Missing Data and the Accuracy of Bayesian Phylogenetics. J. Syst. Evol. 2008, 46, 307-314. [CrossRef]

28. Katoh, K.; Standley, D.M. MAFFT Multiple Sequence Alignment Software Version 7: Improvements in Performance and Usability. Mol. Biol. Evol. 2013, 30, 772-780. [CrossRef]

29. Lanfear, R.; Calcott, B.; Ho, S.Y.W.; Guindon, S. PartitionFinder: Combined Selection of Partitioning Schemes and Substitution Models for Phylogenetic Analyses. Mol. Biol. Evol. 2012, 29, 1695-1701. [CrossRef] [PubMed]

30. Ronquist, F.; Teslenko, M.; Van Der Mark, P.; Ayres, D.L.; Darling, A.; Höhna, S.; Larget, B.; Liu, L.; Suchard, M.A.; Huelsenbeck, J.P. Mrbayes 3.2: Efficient Bayesian Phylogenetic Inference and Model Choice across a Large Model Space. Syst. Biol. 2012, 61, 539-542. [CrossRef] [PubMed]

31. Bodner, M.R.; Maddison, W.P. The Biogeography and Age of Salticid Spider Radiations (Araneae: Salticidae). Mol. Phylogenet. Evol. 2012, 65, 213-240. [CrossRef]

32. Hedin, M.; Maddison, W.P. A Combined Molecular Approach to Phylogeny of the Jumping Spider Subfamily Dendryphantinae (Araneae: Salticidae). Mol. Phylogenet. Evol. 2001, 18, 386-403. [CrossRef] [PubMed]

33. Maddison, W.P.; Li, D.; Bodner, M.; Zhang, J.; Xu, X.; Liu, Q.; Liu, F. The Deep Phylogeny of Jumping Spiders (Araneae, Salticidae). ZooKeys 2014, 87, 57-87. [CrossRef]

34. Maddison, W.P.; Maddison, D.R.; Derkarabetian, S.; Hedin, M. Sitticine Jumping Spiders: Phylogeny, Classification, and Chromosomes (Araneae, Salticidae, Sitticini). ZooKeys 2020, 2020, 1-54. [CrossRef] [PubMed]

35. Adeniran, A.A.; Hernández-Triana, L.M.; Ortega-Morales, A.I.; Garza-Hernández, J.A.; Cruz-Ramos, J.; J. de la Chan-Chable, R.J.; Vázquez-Marroquín, R.; Huerta-Jiménez, H.; Nikolova, N.I.; Fooks, A.R.; et al. Identification of Mosquitoes (Diptera: Culicidae) from Mexico State, Mexico Using Morphology and COI DNA Barcoding. Acta Trop. 2021, 213, 105730. [CrossRef] [PubMed]

36. Mulcahy, D.G.; Macey, J.R. Vicariance and Dispersal Form a Ring Distribution in Nightsnakes around the Gulf of California. Mol. Phylogenet. Evol. 2009, 53, 537-546. [CrossRef]

37. Burge, D.O.; Thorne, J.H.; Harrison, S.P.; O’Brien, B.C.; Rebman, J.P.; Shevock, J.R.; Alverson, E.R.; Hardison, L.K.; RodrÍguez, J.D.; Junak, S.A.; et al. Plant Diversity and Endemism in the California Floristic Province. Madroño 2016, 63, 3-206. [CrossRef]

38. Vanderplank, S.E.; Rebman, J.P.; Ezcurra, E. Where to Conserve? Plant Biodiversity and Endemism in Mediterranean Mexico. Biodivers. Conserv. 2018, 27, 109-122. [CrossRef]

39. Hill, D.E.; Edwards, G.B. Origins of the North American Jumping Spiders (Araneae: Salticidae). Peckhamia 2013, $107,1-67$.

40. Stockwell, D.R.B.; Peterson, A.T. Effects of Sample Size on Accuracy of Species Distribution Models. Ecol. Modell. 2002, 148, 1-13. [CrossRef]

41. Faith, D.P. Conservation Evaluation and Phylogenetic Diversity. Biol. Conserv. 1992, 61, 1-10. [CrossRef] 